\title{
Effects of Substance/Drug Abuse on the Academic Achievement of Secondary School Students in Mkar Metropolis, Gboko, Benue State
}

\author{
Emmanuel Okechukwu Chukwu', Valentine Terhemba Pius ${ }^{2}$, Terna Mesuur Fiase ${ }^{1}$, Habu Haruna ${ }^{3}$, \\ Chia Terkuma ${ }^{1}$, Achukwu Chinyere Evangeline ${ }^{1}$ \\ ${ }^{1}$ School of Nursing Mkar, Gboko, Nigeria \\ ${ }^{2}$ School of Nursing Makurdi, Makurdi, Nigeria \\ ${ }^{3}$ Department of Nursing Science, University of Maiduguri, Maiduguri, Nigeria
}

Email address:

emmanwaguy42@yahoo.com (E. O. Chukwu)

\section{To cite this article:}

C. Emmanuel Okechukwu Chukwu, Valentine Terhemba Pius, Terna Mesuur Fiase, Habu Haruna, Chia Terkuma, Achukwu Chinyere Evangeline. Effects of Substance/Drug Abuse on the Academic Achievement of Secondary School Students in Mkar Metropolis, Gboko, Benue State. International Journal of Psychological and Brain Sciences. Vol. 2, No. 2, 2017, pp. 40-45. doi: 10.11648/j.ijpbs.20170202.12

Received: February 24, 2017; Accepted: March 8, 2017; Published: March 23, 2017

\begin{abstract}
This study is cross-sectional descriptive survey which was carried out to find out the effect of substance/drug abuse on the academic achievement of secondary school students in Mkar metropolis, Mkar, Gboko, Benue State. A sample size of 220 secondary school students was selected using simple random sampling technique after the schools were purposively selected for the study. 220 questionnaires were distributed as method of data collection, collected back and analysed. Findings revealed that most students, $118(53.6 \%)$ are between the age of 15 and 19 years. $203(92.3 \%)$ of the respondents are Tiv. 98 (44.5\%) were of the opinion that these abused substance/drugs are always available. Findings also revealed that 49 (22.3\%) abuse Amphetamines like Tramol, Tramadol or Tradyl. 50 (22.7\%). The research also shows that poor academic performance is one of the effects of this substance /drugs on the student. Other effects includes truancy and decreasing their ability to concentrate.70 (31.8\%) of respondents believed instituting early detection programs in school will be a great preventive strategy or solution to reducing the rate of these substance/drug abuse. Recommendations were made which include Substance/Drug free clubs should be established in secondary schools, Counselling education should be introduced in secondary schools and it should involve parents/guardians, designing curricula on drug education, etc. Emphasis should be placed on health education as this will help families in planning the academic future of their children, the family and nation as a whole.
\end{abstract}

Keywords: Effects, Substance, Abuse, Academic, Achievement, Secondary, Students

\section{Introduction}

Historically, the use of psychoactive substances or drugs can be said to be a universal phenomenon found among such diverse people as the Fangs of North Western Equatorial Africa, the Aryans of Northern India, the Jivaro of the Amazonian rain forest, the Aborigenes of Australia, the Reindeer Herders of Siberia (Hollister, 1972).

Substance or drug abuse problem encompasses medical, social cultural and other variables and is not a merely medical or moral problem. According to Schmelleger (2002), people accept the use of some substances or drugs under certain circumstances as benign and even beneficial practice through connection to social and individual situations. The use of drugs like Benylin with codeine, Tutolin with codeine, for medical purposes like whooping cough is not a drug abuse but becomes abuse only when it is geared towards producing some desired behaviours, physical dependency, addiction and/or constitute a nuisance to the society. According to Abdullahi (2005), the term substance/drugs is a abroad name that is not restricted to oral therapy (i.e. injection, capsules or tablets) but includes marijuana, alcohol as well as traditional alcoholic drinks like Ogogoro, Burukutu, Fito and Bammi. 
Nigerians make use of different substances/drugs just in the same way as this is done in many other societies. The population in Nigeria avails itself of substances/drugs when the occasion warrants them just as other population in the world do. Substances/drugs are abused in Nigeria simply because they are used without due authorization from formally qualified and registered persons who according to the laws of the land must approve their use. This observation is borne out by several studies on illness behaviour among Nigerians (Fawa, 2003; Obiamaka, 2004). According to Kalunta (2000), the most common substances/drug abuse in Nigeria are marijuana, amphetamines, mandrax, proplus, barbiturates and codeine that have negative effects to the youths, immediate society and Nigeria at large. Therefore, the essence of this research work is to study the effect of substance abuse on the academic achievement of secondary school students in Mkar metropolis, Gboko, Benue state, Nigeria.

Unfortunately, youth that constitute the manpower and future of Nigerian society are mostly the victims (Abdullahi, 1991). Federal Ministry of Youths and Sport 2010 observed that, Nigerian youths aged 10-30 years are about $49 \%$ of the country's population. National Drug Law Enforcement Agency (2010) observed that, over 38\% of Nigerian Youths abuse drugs. According to Abang (2006), in contemporary Nigeria, many categories of youths (male and female) are hooked on substance/drug abuse problem. This include an unbelievable large number of primary and secondary school pupils, undergraduate students, servicemen, cattle rearers, unemployed, nurses, pharmacists, and even medical doctors.

According to Abdullahi (2005), substance/drug abuse leads to high rate of crime, fuel conflict, political thuggery, religious intolerance, raping, domestic violence, suicide, etc in the society. It also affects the psychological and physical conditions of abusers.

\subsection{Aims and Objectives of the Study}

The specific objectives of the study are to;

a. Determine the extent to which substance abuse Influences Student's Academic Achievement among secondary school students in Mkar metropolis, Gboko, Benue State.

b. Identify the most commonly abused substances or drugs among the students.

c. Evaluate the effects of these abused substances on Academic achievement of the students.

d. Identify ways of reducing the abuse of substances/drugs.

\subsection{Research Hypothesis}

The hypothesis formulated for the study is as follows:

$\mathrm{H}_{\mathrm{o}}$. There is no significant relationship between substance abuse and academic achievement of secondary school students in Mkar metropolis, Gboko. Benue state.

\section{Research Methodology}

\subsection{Research Design}

The researcher used a descriptive cross sectional study design with emphasis on finding out the effect of substance abuse on the academic achievement of secondary school students in Mkar metropolis, Gboko, Benue state. This design was used because a large number of participants were involved. Also, because the whole data was collected from participants all at once.

\subsection{Study Population}

The study population consists of some selected secondary school students with emphasis on those in senior secondary section (SSS). The schools selected include;

$\begin{array}{ll}\text { Schools } & \text { Total Population } \\ \text { NKST College Mkar. Mkar } & 205 \\ \text { Mkar Model College, Mkar } & 312 \\ \text { Sky Gifted Academy Mkar, Mkar } & 141 \\ \text { NKST Secondary School Mkar } & 223 \\ \text { Kings Comprehensive College } & 227 \\ \text { Total } & 1108\end{array}$

\subsection{Sample and Sampling Technique}

A simple random technique was used to select some of the secondary schools to be used for the study. The sample size was $20 / 100 \times 1108 / 1=221.6$ that is 220 . The first stage involves selection of secondary schools where the students will be selected from. This will be a purposive sampling because both private and public schools will be involved. The questionnaire will be administered to 220 representing about $20 \%$ of students.

\subsection{Instrumentation}

The researchers used the questionnaire to conduct the research. The questionnaire for the study was self-structured and validated which contains 24 questions that are relevant to the purpose of the study.

\subsection{Method of Data Collection}

The self-administered questionnaire was given to the students in their classes during school hours. The questionnaire contained information such as bio data, knowledge about substances use and abuse. The questionnaire was then retrieved immediately after completion.

\subsection{Method of Data Analysis}

A descriptive statistical method was used to analyze the collected data and the chi - square to test the statistical significance of the relationship between the variables being studied.

\subsection{Ethical Consideration}

In carrying out the research, the principle of voluntary participation where participants were not coerced into participation was ensured. Also the confidentiality was maintained by keeping information given by respondents away from those not directly involved in the study. 


\section{Data Analysis, Presentation and Discussion}

Socio-demographic data.

Table 1. Sex of Respondents $(N=220)$.

\begin{tabular}{lll}
\hline Sex & No & Percentage (\%) \\
\hline Males & 143 & 65 \\
Females & 77 & 35 \\
Total & 220 & 100 \\
\hline
\end{tabular}

Table 1 above shows that, $143(65 \%)$ of the respondents were Male and $77(35 \%)$ were Female that participated in the study.

Table 2. Age of Respondents $(N=220)$.

\begin{tabular}{lll}
\hline Age & No. & Percentage (\%) \\
\hline $10-14$ & 12 & 5.5 \\
$15-19$ & 118 & 53.6 \\
$20-24$ & 76 & 34.5 \\
25 and Above & 14 & 6.4 \\
Total & 220 & 100 \\
\hline
\end{tabular}

Table 2 shows that the age of the respondents were 10-14, $12(5.5 \%)$, those between age $15-19$ were $118(53.6 \%)$, age 20 -24 were $76(34.5 \%)$, and those whose age was 25 and above were 14 (6.4\%).

Table 3. Tribe of respondents $(N=220)$.

\begin{tabular}{lll}
\hline Tribe & No. & Percentage (\%) \\
\hline Tiv & 203 & 92.3 \\
Idoma & 9 & 4.1 \\
Igede & 2 & 0.9 \\
Others & 6 & 2.7 \\
Total & 220 & 100 \\
\hline
\end{tabular}

Table 3 shows that respondents who were Tiv were 203 (92.3\%), Idoma $9(4.1 \%)$, Igede $3(1.4 \%)$ and $6(2.7 \%)$ consisted of other tribes.

Table 4. Disposition of Respondents $(N=220)$.

\begin{tabular}{lll}
\hline Disposition & No. & Percentage (\%) \\
\hline Sciences & 37 & 16.8 \\
Social Sci. & 42 & 19.1 \\
Arts & 56 & 25.5 \\
Commercial & 46 & 20.9 \\
General & 39 & 17.7 \\
Total & 220 & 100 \\
\hline
\end{tabular}

Table 4 As regards the students dispositions in school, 37 $(16.8 \%)$ were offering Science subjects, 42 (19.1\%) were in the Social Sciences, 56 (25.5\%) were offering art subjects, 46 $(20.9 \%)$ were in commercial classes and 39 (17.7\%) were offering all general subjects.

Table 5. Section/Class of Respondents $(N=220)$.

\begin{tabular}{lll}
\hline Section/ Class & No. & Percentage (\%) \\
\hline SSS 1 & 43 & 19.5 \\
SSS 2 & 75 & 34.1 \\
SSS 3 & 102 & 46.4 \\
Total & 220 & 100 \\
\hline
\end{tabular}

Table 5 Shows that the respondents consists of $43(19.5 \%)$ SSS 1 students, 75 (34.1\%) from SSS 2 and 102 (46.4\%) from SSS 3 .

Table 6. Residence of Respondents $(N=220)$.

\begin{tabular}{lll}
\hline Place of Residence & No. & Percentage (\%) \\
\hline School Hostel & 27 & 12.3 \\
Rent outside school & 16 & 7.3 \\
Staying with parent/guardian & 142 & 64.5 \\
Staying outside the school with schoolmate (s) & 35 & 15.9 \\
Total & 220 & 100 \\
\hline
\end{tabular}

Table 6: Shows 27 (12.3\%) resided in the school hostel, 16 $(7.3 \%)$ rented and stay in houses outside the school. 142 $(64.5 \%)$ who were staying outside the school hostel live with their parent/guardian, while $35(15.9 \%)$ stay outside with other classmate/schoolmates.

\subsection{Demographic Data of Respondents}

From the research carried out, it will be observed that majority of the substance/drug users were $143(65.0 \%)$ males even though the involvement of $77(35.0 \%)$ females was also evident. The research also shows that most (53.6\%) of the students that involved in substance/drug use and abuse fall between the age bracket of 15-19 years and these findings correspond with the view of WHO and The World's Heart foundation data as sited by Staff (2012) which posit that in Nigeria, $22.1 \%$ of school youth age between 12 to 17 years use tobacco.

\subsection{Causes of Substance Abuse Among Secondary School Students in Mkar Metropolis, Gboko, Benue State}

Table 7. Causes of substance/drug abuse in schools $(N=220)$.

\begin{tabular}{lll}
\hline Options & No & Percentage (\%) \\
\hline Curiosity & 22 & 10 \\
Peer Group Influence & 50 & 22.7 \\
Lack of parental care/supervision & 16 & 7.3 \\
$\begin{array}{l}\text { Personality Problems due to socio-Economic } \\
\text { Conditions }\end{array}$ & 23 & 10.5 \\
The Need for Energy to Work for Long & 25 & 11.5 \\
$\begin{array}{l}\text { Hours } \\
\text { Hedonism }\end{array}$ & 10 & 4.5 \\
Availability of the Substance/Drugs & 44 & 20.0 \\
The Need to prevent the Occurrence of & 30 & 13.6 \\
Withdrawal symptoms & 220 & 100 \\
Total & & \\
\hline
\end{tabular}

The 7 above revealed that $22(10.0 \%)$ of the respondents took these substances or drug out of curiosity. 50 (22.7\%) responded that peer group influence was the cause. $16(7.3 \%)$ responded that lack of parental care or supervision made them got involved in the abuse of these substance. 23 $(10.5 \%)$ Opined that personality problems due to socioeconomic conditions is the cause of substance abuse. 25 $(11.5 \%)$ say they take these substance when they intend working for long hours. $10(4.5 \%)$ were of the belief that Hedonism is the cause of substances/drugs abuse. 44 (20.0\%) respondents felt the availability of these substance/drug is the cause and $30(13.6 \%)$ see the need to prevent the occurrence 
of withdrawal symptoms as the cause of substance/drug abuse in schools.

This is in accordance with the research carried out by Haladu (2003) who gave the aforementioned reasons as the causes of substance/drug abuse and another study by Afolayan and Afolayan (2010) where they identified two primary causes of drug abuse and addiction such as: peer pressure and depression. Abdu-Raheem (2013) also found peer-pressure and availability as cause for drug abuse among students.

\subsection{Most Common Substances or Drugs Abused By the Students}

Table 8. Most Common Substance/drug abused by student $(N=220)$.

\begin{tabular}{|c|c|c|}
\hline Substance/drug & No. & Percentage (\%) \\
\hline Human feaces & 07 & 3.2 \\
\hline Stagnant gutter residue & 11 & 5.0 \\
\hline Sedative e. g Brukutu, Pito, alcohol & 30 & 13.6 \\
\hline Amphetamines e. g Tramol, Tramadyl, Tradyl & 49 & 22.3 \\
\hline $\begin{array}{l}\text { Narcotics e. g Cocaine, Codein, Heroin, } \\
\text { Morphein }\end{array}$ & 24 & 10.9 \\
\hline $\begin{array}{l}\text { Inhalants e. g Chemicals in Gasoline, } \\
\text { Petroleum, Glue, Solution }\end{array}$ & 26 & 11.8 \\
\hline $\begin{array}{l}\text { Marijuana and Cigarette i.e Morocco, Ganye, } \\
\text { Stone, Wee-wee, Iegbo, wrap, Cigar, e. t. c }\end{array}$ & 43 & 19.5 \\
\hline $\begin{array}{l}\text { Cough Syrup with codein e. g Perkalin, } \\
\text { Benilin, tutolin }\end{array}$ & 14 & 6.4 \\
\hline $\begin{array}{l}\text { Others e. g aspirin, cannabis, inhalation of pit } \\
\text { laterine. }\end{array}$ & 16 & 7.3 \\
\hline Total & 220 & 100 \\
\hline
\end{tabular}

Table 8 above shows the most common substance/drugs abuse by students. It has clearly shown that $07(3.2 \%)$ respondents abuse substance like human feaces, 11 (5.0\%) Stagnant gutter residue. 30 (13.6) abuse sedatives like alcohol, $49(22.3 \%)$ abuse Tramol, tramadol or tradyl. Narcotics like Cocaine, Heroin and Morphein accounted for $24(10.9 \%)$. Information generated also shows the wide spread of Marijuana and cigarette with 43 (19.5\%), Cough syrup with codein $14(6.4 \%)$ and $16(7.3 \%)$ accounted for other stimulant.

This finding agrees with that conducted by Double Gist (2013) which mentioned all of the substances abused by the respondents as shown above likewise that carried out by Okonkwo et al (2012) who mentioned in their study that human feaces and stagnant gutter residue were among the substances abused by adolescence.

\subsection{Effects of These Abused Substances or Drugs on the Academic Achievements of Secondary School Students}

Table 9. Effect of substance/drug abuse on academic achievement $(N=220)$.

\begin{tabular}{llllll}
\hline Effect of substance/drugs & SA & A & D & SD & Total \\
\hline Poor academic performance & 40 & 58 & 68 & 54 & 220 \\
Truancy & 48 & 87 & 46 & 39 & 220 \\
Decrease ability to concentrate & 80 & 39 & 33 & 68 & 220 \\
Poor self-control & 63 & 24 & 38 & 95 & 220 \\
High level of conflict & 79 & 38 & 46 & 57 & 220 \\
Total & 310 & 246 & 231 & 313 & 1100 \\
\hline
\end{tabular}

Table 9 of the study shows the effect of these abused substance/drugs on the academic achievements of students and it reveals effects like poor academic performance, truancy, decrease ability to concentrate, poor self-control, high level of conflict. This study is in agreement with that carried out by Fayombo and Aremu (2000) on the effect of drug abuse on educational performance of some adolescent drug abusers in Ibadan which found that the misuse of marijuana had reached an epidemic level in the present Nigeria society, and that drug abuse could lead to reduce academic achievement or even halt one's entire academic process. This is also in line with a study by Odejide (1997) which shows that adolescents who abuse substances typically do more poorly in academic. Poor academic performance, prone to anger and violence, and truancy were some of the major effects of drug abuse among students (Attah, Baba and Audu, 2016; Agbonghale and Okaka, 2014; Ana, Laura and Micheal, 2012; Abdullahi, 2011).

\subsection{Ways of Reducing the Rate of Substances Abuse}

Table 10. Way (s) of reducing the rate substance/drug problem $(N=220)$.

\begin{tabular}{|c|c|c|}
\hline Preventive strategies & No. & Percentage (\%) \\
\hline Placing Ban on Over the Counter (OTC) sales of these substances/drug & 31 & 14.1 \\
\hline Awareness creation on the dangers of substance/drug abuse & 45 & 20.5 \\
\hline Instituting early detection programmes in schools & 70 & 31.8 \\
\hline $\begin{array}{l}\text { Others e. g people involve in the sale of these substances should be arrested and locked up, students found dealing in substance } \\
\text { or drugs should be expelled from school instantly and those under the influence of these substance should not be permitted to sit } \\
\text { for exams. }\end{array}$ & 12 & 5.5 \\
\hline
\end{tabular}

Table 10 shows that $31(14.1 \%)$ believed placing Ban on Over the counter drug will be a great strategy, 45 (20.5\%) believed awareness creation on the dangers of substance/drug abuse could be a preventive strategy. However 70 (31.8\%) respondents suggested the institution of early detection programs in schools, $62(28.2 \%)$ say strict monitoring of pharmaceutical shops/chemists around Mkar Metropolis will curb the problem. Other option suggested by $12(5.5 \%)$ were that people involve in the sale of these substances should be arrested and locked up, student found dealing in substance or drugs should be expelled from school instantly, student under the influence of this substance should not be permitted to sit for exams among others.

This is actually the findings that corresponds with the 
WHO (2000) Primary level of prevention which aims at emphasizing on the realistic risks associated with drug and alcohol abuse. In order to formulate a realistic primary prevention program the following should be considered. It further stated that the program's must provide knowledge on effects of drug abuse, life skills like communication, assertiveness, decision making and coping social skills.

\subsection{Testing Hypothesis.}

\section{Hypothesis}

Ho. There is no significant relationship between substance abuse and academic achievement of secondary school students in Mkar metropolis, Gboko. Benue state

To test this hypothesis we use;

Table 11. Effect of substance/drug abuse on academic achievement ( $N=220)$.

\begin{tabular}{llllll}
\hline Variables & SA & A & D & SD & Total \\
\hline Poor academic performance & 40 & 58 & 68 & 54 & 220 \\
Truancy & 48 & 87 & 46 & 39 & 220 \\
Decrease ability to & 80 & 39 & 33 & 68 & 220 \\
concentrate & 63 & 24 & 38 & 95 & 220 \\
Poor self-control & 79 & 38 & 46 & 57 & 220 \\
High level of conflict & 310 & 246 & 231 & 313 & 1100 \\
Total & & & &
\end{tabular}

Calculated Chi - square $\left(x^{2}\right)=2508.9$

$$
\text { Level of Significance }=0.05
$$

Degree of freedom $(\mathrm{D} f)=($ Row -1$)($ Column -1$)$

$$
\begin{aligned}
& (5-1)(4-1) \\
& \text { (4) }(3)=12
\end{aligned}
$$

At Degree of freedom 12 and 0.05 Level of Significance, Table value $\left(x^{2}\right)=21.026$.

Thus, since calculated Chi- square $\left(x^{2}\right) 2508.9$ is greater than the table critical value 21.026 , is rejected. This means that the alternative hypothesis which states that there is significant relationship between substance abuse and academic achievement of secondary school students in Mkar metropolis, Gboko. Benue state is accepted.

\section{Conclusion}

From empirical evidence and feed-back from the respondents, the papers has revealed that Substance/drug abuse and addiction have adversely affected the academic performance of students. More so, the social and psychological implications of substance/drug abuse and addiction have resulted into student lateness to class exam malpractices, absenteeism and other form of criminality both within and outside the school environment and in the society (nation) as a whole. Thus the null hypothesis was rejected meaning there is significant relationship between substance abuse and academic achievement of secondary school students in Mkar metropolis Gboko. Benue state.

Finally, the research revealed that most causes and reason given for substance/drug abuse are highly insignificant and do not have any moral and social justification as it rather lead to demoralization and social disorder in the society.

\section{Recommendation}

The research recommends that:

1. Government should prevent the cultivation/sales of Indian Helm and other deadly herbs that encourage drug abuse.

2. Government should strictly enforce its existing laws against drug abuse through its regulatory agencies.

3. Parents and guardians should Endeavour to monitor their children and wards so that they do not engage in substance/drug abuse.

4. School security should be heightened and regular check should be carried out.

5. Substance/Drug free clubs should be established in secondary schools.

6. Effort of the school authority should be geared towards intensive use of print and electronic media for public enlightenment.

7. Counseling education should be introduced in secondary schools and it should involve parents/guardians to revive those who have already been engaging in the act and thus reduce substance/drug abuse among adolescence.

8. Establishment of Family Education on Drugs: The family is the nucleus of the social organization. Parents should give their children appropriate education on drug use. They should be encouraged by health authorities to offer family education on substance/drug abuse to their children. They should inform them of the dangers of substance/drug abuse and dependence on their health, society and the nation.

9. Establishment of Counseling Centers for Drug Control: Counselling centers should be established in every community by the government or private individuals. Qualified health counsellor should be employed in helping drug addicts or those dependent on substances/drugs by giving them special advice on how to go about the withdrawal system.

10. Designing Curricula on Drug Education: Ministry of education (State and Federal) should as matters of urgency add to the curricula- drug education at all levels of education.

11. Campaign against Drug Abuse: National Drug Law Enforcement Agency (NDLEA) should intensify their campaigns on antidrug in order to have a drug free society. The campaign against use of certain substance/drugs and misuse of drugs should be more intensified at the secondary school level because it is the peak of adolescent. Also, government and other relevant authorities should lunch out campaigns against drug abuse as well as dependence.

12. Effective study Habit for Students: An effective study is that which centers on a well-planned scheme of 
study involving sufficient recreational activities, enough resting time and sleep. Thus, such well-planned time table of study habits that make adequate provision for rest will enhance good study habit without necessary resorting to the use of substances/drugs to keep students artificially awake.

13. Establishment of Drug Awareness Units: Drug awareness units to be set up in all states and moderated by the federal state and local governments. It should not be a panel established to try people who use drugs as criminals, but to help solve their socio-psychological problem. Parents and adults should refrain from using drugs in discriminately in the presence of youngsters and they should discourage their wards/children from associating with "unknown", gangs or suspicious neighborhood peer groups.

\section{References}

[1] Abang, E. (2006). Youth Involvement in Illicit Drugs: Impact on National Development. Paper Delivered at Federal Polytechnic Auchi Student Union Week. May 22-26.

[2] Abdullahi, S. A. (1991) Poverty and Drug Abuse; A Study of Dawanau Rehabilitation Centre, Kano Studies. 1:23-29.

[3] Abdullahi, S. A. (2005) Community Based Youth Drug Abuse Prevention Strategies"in Dalhatu, S. (ed.) Eassays on Local Government Administration: Fostering Better Service Delivery, Record Keeping, Accountability and Empowerment at Local Government.

[4] Abdullahi, S. M. (2011) Effects of Drug Abuse on Academic Performance Among Secondary School Youths in Garissa Municipality, Kenya. University of Nairobi Research Archive. http://erepository.uonbi.ac.ke:8080/handle/123456789/4749

[5] Abdu-Raheem, B. O. (2013) Sociological Factors To Drug Abuse And The Effects on Secondary School Students' Academic Performance In Ekiti and Ondo States, Nigeria. Contemporary Issues in education Research- Second quarter, Vol. 6 (2).

[6] Afolayan J. A and Afolayan A. M (2010), Drug Addiction and its academic implications among Secondary School Students in Ilorin South Local Government of Kwara state. Continental Journal of Pharmacology and Toxicology. Research http:/www/wiloludjournal.com

[7] Agbonghale, G. O and Okaka R. O (2014) Effects of Drug Abuse on Academic Performance of Technology Education Students in Nigeria Public Universities. Journal of Psychology Vol.5 (1):79-83.

[8] Ana, I. B, Laura, M. G., and Micheal, T. F (2012) The Effects of Alcohol Use on academic achievement in High School. Econ
Educ Rev. 30 (1):1-15 doi:10.1016/j.econedurev.2010.06.015

[9] Attah, A. P., Baba, E., and Audu, J. S (2016) The Effects of Drug Abuse and Education on Academic Performance of Students in Federal Polytechnic Idah, Kogi State Nigeria. International Journal of Democratic and Development Studies, Vol.2 (2):13-22. ISSN:2350-224x

[10] DoubleGist (2013) Drug Abuse Among Secondary School Students: Implications for Counselling. Retrieved from: www.doublegist.com/drug-abuse-secondary-school-studentsimplications-couneslling/

[11] Fawa, M. S. (2003). Drug abuse eradication programme in schools: The relevance of team, approach alternative, in A. Garba (Ed) Youth and drug abuse in Nigeria: Strategies for counselling, management and control, Kano: Matasa Press.

[12] Fayombo, G. A. \& Aremu, S. (2000). "Drug education and its effects on the educational performance of some adolescents drug abusers in Ibadan”, The Counsellor, 18 (5), pp. 378-387.

[13] Haladu, A. A. (2003). Outreach strategies for curbing drug abuse among out-of-school youth in Nigeria: A challenge for community Based Organization (CBOS), in A. Garba (ed). Youth and drug abuse in Nigeria: Strategies for counselling, management and control. Kano: Matosa Press.

[14] Hollister WP and McGrath JH, (1972). Patent and PortionPrecursor to modern Drug Use and Abuse. Journal of Drug issues, 1 (2) 245-254.

[15] Kalunta (2000). Substance and Drug. Presented at the National Seminar on Drug Abuse Enforcement, Lagos, May. 5 .

[16] NDLEA (2010). Drug safety Report. Lagos.

[17] Obiamaka, V. O. (2004). "Problem behaviours in Nigerian secondary schools", Nigeria Society for Education Psychologists (NISEP), pp. 69-75.

[18] Odejide, A. (1997). "Alcohol use in sub-group literature Nigerian”, African Journal of Psychiatry, Vol. 5, 15-20.

[19] Okonkwo C. J, Valentine T. P, Ogwola O. B, Chinedu O. J, Dashuwar N. P, Alabi F, (2012). Water scarcity, Amoebiasis and Abused substances among youths of Tudun wada district, Jos south LG, Plateau state. PHC posting report. (Unpublished).

[20] Schmelleger (2002). Effects of substances and drug on intellectualism. Journal of education 5 (1\&2), pp. 21-27.

[21] Staff N. E (2012). Drug Abuse in Nigeria Schools: A Study of Selected Secondary Institutions in Bayelsa State, South-South, Nigeria. International Journal of Scientific Research in Education (IJSRE). V.5 (3). 1.

[22] World Health Organization (WHO), (2000). Recommended Levels of substances/drugs prevention. Statistical report. Geneva. 